\title{
Application of Electronic Noses for Disease Diagnosis and Food Spoilage Detection
}

\author{
Ida A. Casalinuovo *, Donato Di Pierro, Massimiliano Coletta and Paolo Di Francesco \\ Divisions of Microbiology and Medical Chemistry, Department of Experimental Medicine and \\ Biochemical Sciences, Faculty of Medicine and Surgery, University of Rome “Tor Vergata”, Via \\ Montpellier n²1, 00133 Rome, Italy \\ * Author to whom correspondence should be addressed: E-mail: casalinuovo@med.uniroma2.it; Tel. \\ +39-06-72596565 / 6579; Fax: +39-06-20427523
}

Received: 22 September 2006; in revised form: 28 October 2006 / Accepted: 30 October 2006 / Published: 1 November 2006

\begin{abstract}
Over the last twenty years, newly developed chemical sensor systems (socalled "electronic noses") have odour analyses made possible. This paper describes the applications of these systems for microbial detection in different fields such as medicine and the food industry, where fast detection methods are essential for appropriate management of health care. Several groups have employed different electronic noses for classification and quantification of bacteria and fungi to obtain accurate medical diagnosis and food quality control. So far, detection and identification of bacterial and fungal volatiles have been achieved by use of e-noses offering different correct classification percentages. The present review includes examples of bacterial and fungal species producing volatile compounds and correlated to infectious diseases or food deterioration. The results suggest the possibility of using this new technology both in medical diagnostics and in food control management.
\end{abstract}

Keywords: electronic noses, microorganisms, spoilage, clinical samples.

\section{Introduction}

The electronic nose instrumentation was developed in the early 1980s [1]. Since then, the analyses of volatile compounds have been of increasing interest and many studies have been dedicated to the improvement of odour measurements. 
This technology aims to mimic the mammalian sense of smell by producing a composite response unique to each odorant. The system comprises a set of active materials that detects the odour and transduces the chemical vapours into electrical signals. The odour profile or "fingerprint" obtained can then be analysed using a pattern recognition program; statistical methods, e. g. Principal Components Analysis (PCA), Cluster Analysis (CA) and/or Neural Network Algorithms, are provided for data processing [2-3].

The first developed sensor array was a Metal Oxide Semiconductor (MOS), which detected 20 odours [1]. Technological advances made it possible to create sensor arrays (from six up to 32 sensors) with different materials, processing thousands of smells. This equipment comprises different types of sensors interacting with volatiles: Metal Oxide Semiconductor Field Effect Transistors (MOSFETs), Quartz Crystal Microbalances (QCMs), the Surface Acoustic Waves (SAWs), Conducting Organic Polymer Sensors (CPs), Intrinsically Conducting Polymers (ICPs) and optical fiber bundles [4-8]. Modern electronic noses (e-noses) can be constructed with more than one type of sensor in them. The development of gas chromatographic (GC) detectors together with direct column heating has recently produced a new type of ultra-fast gas chromatograph, called zNose ${ }^{\mathrm{TM}}$ [9-11]. All the devices listed above are designed for experimental procedures, data analysis and comparative evaluation of results (data treatment).

The applications of this technology range from environmental analysis and food processing to the pharmaceutical industry and medicine [12-16]. Electronic noses offer great potential for the detection of different microbial species. Some chemical products are specific to fungal and bacterial species and are commonly used as a useful diagnosis tool. Recently, it has been shown that the volatile compounds produced by these microorganisms during growth can be detected by the e-nose and recognized according to a pattern model [17-18].

Off-flavours in foods originate mostly from bacterial and/or fungal metabolism and several studies have been carried out on the detection of the volatile chemicals produced from the microorganisms mentioned. The isolated species include gram-negative, gram-positive bacteria and several fungi [1922]. The risk of fungal contamination is also related to several mycotoxigenic species that produce mycotoxins very harmful to human and animal health.

Therefore, early detection of the microorganisms offers many advantages for quality control in the foodstuffs industry. Similarly, specific volatile compounds have been identified and related to the growth of several microorganisms in biological samples and these results promise to be useful for medical diagnostics [23-26].

In this paper we review the results obtained by these instruments employed for the identification of microorganisms related to: i) infectious diseases, ii) food and beverage spoilage.

\section{Sampling for detection and diagnosis of infection}

\subsection{Clinical samples and rapid diagnosis}

Different sampling methods have been used for the volatile compounds detection in order to distinguish between normal and infected specimens and to see whether the pathogens might be detectable among other species. In the field of clinical microbiology, classical cultivation and isolation 
methods are laborious and time consuming. The rapid screening of biological samples could allow faster and appropriate therapeutic treatment and would lead to a mortality rate decrease [23].

Consequently, several studies have been performed on biomedical specimens for rapid, nearpatients diagnosis using e-noses. Table 1 provides a summary of microorganisms detected in clinical specimens by e-noses. In urinary tract infections e-noses were used to analyze urine samples directly or after short incubations in test tube systems containing complex media [27-29]. Moreover, a variety of data reduction and pattern recognition techniques are proposed to discern the species and/or different metabolic states of the bacteria [30-31]. In particular, it is reported that an e-nose was able to distinguish between uninfected and infected urine with Escherichia coli, Proteus mirabilis and Staphylococcus sp. [31].

Table 1. Application of the e-nose on biomedical samples for rapid microbial diagnosis.

\begin{tabular}{|c|c|c|c|}
\hline Disease & Sample & $\begin{array}{l}\text { Bacterial species detected* } \\
\text { or screening for infection }\end{array}$ & Literature cited \\
\hline Leg infections & Ulcers & Positive & {$[23]$} \\
\hline $\begin{array}{l}\text { Urinary tract } \\
\text { infections }\end{array}$ & Urine & $\begin{array}{l}\text { Staphylococcus aureus } \\
\text { Escherichia coli } \\
\text { Proteus mirabilis } \\
\end{array}$ & {$[27-31]$} \\
\hline $\begin{array}{l}\text { Sinusitis } \\
\text { Pneumonia }\end{array}$ & Breath & Positive & [32-34] \\
\hline Tuberculosis & Sputum & $\begin{array}{l}\text { Mycobacterium tuberculosis } \\
\text { Mycobacterium avium } \\
\text { Pseudomonas aeruginosa }\end{array}$ & [35] \\
\hline Bacterial vaginosis & Swabs & Positive & {$[36-37]$} \\
\hline $\begin{array}{l}\text { Ear, nose, throat } \\
\text { infections }\end{array}$ & Swabs & $\begin{array}{l}\text { Staphylococcus aureus } \dagger \\
\text { Pseudomonas aeruginosa } \\
\text { Streptococcus pneumoniae } \\
\text { Streptococcus pyogenes } \\
\text { Haemophilus influenzae }\end{array}$ & [38-40] \\
\hline
\end{tabular}

* The samples were analysed using traditional cultural methods for confirmation.

${ }^{\dagger}$ Including both methicillin-resistant and methicillin-susceptible.

Prospective studies have been performed to determine whether exhaled gas or breath analysis using an e-nose correlates with pneumonia scores or sinusitis. The results show good correlation with clinical diagnosis and provide new potential for diagnostic analysis [32-34].

Using an e-nose based on electroconductive polymers, Pavlou et al. examined the potential for the detection of Mycobacterium tuberculosis in sputum samples. These authors have shown, for the first time, that it is possible to discriminate effectively between human sputum samples infected with $M$. tuberculosis, M. avium, Pseudomonas aeruginosa, a mixed infection and the controls [35]. The 
finding, although preliminary, is very encouraging and provides a rapid means to identify the organisms causing respiratory infections.

Finally, preliminary studies have also reported that e-nose can provide a promising means for detecting and identifying bacteria in vaginal, nasal, ear and throat swabs [36-40]. Further improvement of these studies could enable rapid diagnosis of bacterial vaginosis and upper respiratory infections.

\subsection{Bacterial species and biochemical precursors}

The studies described above are based on the development of new fast methods for monitoring bacteria vapours on the patient or directly in the clinical specimens. In other experimental work, artificial media have been employed to obtain from each microorganism biochemical pathways leading to the production of characteristic odours. In these experiments the microorganisms were previously isolated and inoculated in complex nutrient media. These studies explored the potential for discrimination between disease-causing pathogens and other isolates, by inducing biochemical precursors for the liberation of specific odours. The results showed that it is possible to discriminate between clinical anaerobic isolates of Clostridium sp. and Bacteroides fragilis collected from intraabdominal infections [41]. Detection of microorganisms causing Helicobacter pylori infection [42] and other bacteria causing urinary tract infections was also achieved [31].

One of the aims of these experiments was also to provide a faster identification of the specific pathogens by reducing the incubation time of the cultures. Recently, a fast method to identify ten pathogenic organisms using an e-nose has been reported: these studies show that an incubation of 16 hours is sufficient to produce measurable volatile compounds [43]. Gardner et al. have also obtained important results by sampling bacteria such as E. coli and $S$. aureus during their growth phase. In this context, $100 \%$ of $S$. aureus were correctly classified during the first hour of incubation and in the lag phase [44-45]. Since the specific metabolites reflect the bacterial growth, it could be possible in the future to detect important vapours as markers of the different bacterial species. This could enable the development of specific sensors to obtain improvement in the discrimination patterns and rapid screening for diagnosis [46].

\section{E-noses for detection of foods and beverage spoilage}

In the food-processing industry quality assurance systems need to be rapid and range from organoleptic measurement to microbiological surveys. Generally, qualitative assessment of food spoilage is made by human sensory panels that evaluate air samples and discriminate which food products are good or unacceptable. Quantitative characterization is then made by gas chromatography and mass spectral analysis [47-48]. Compared to this methodology, the e-noses can perform odour detection continually and are not subject to individual sensitivity.

Bacterial contamination of food and drinks can generate unpleasant odours and toxic substances. Therefore, different industries are interested in the application of the e-nose both for monitoring of storage quality degradation and for detecting microbial contaminants.

One of the earliest reports of e-nose technology applied to food analysis concerned the vapours produced by microorganisms involved in sausage fermentation [49]. Subsequently, Arnold and Senter 
reported that bacteria isolated from processed poultry were cultured to evaluate the profiles of volatile compounds generated and the e-nose was able to distinguish each of the isolated species [50].

Early detection of milk spoilage as well as different concentrations of spoilage bacteria and yeasts were also investigated. The results of these studies showed that, using an e-nose system, it could distinguish between volatile profiles of different species inoculated in milk-based media after two and five hours of incubation. Moreover, three bacterial concentrations of Pseudomonas aureofaciens (10 ${ }^{6}$ cells $/ \mathrm{mL}, 3.5 \times 10^{8}$ cells $/ \mathrm{mL}$, and $8 \times 10^{8}$ cells $/ \mathrm{mL}$ ) were clearly discriminated [51]. Although under development, these studies confirm the results of different works that explored the application of different gas sensors in the detection and identification of bacteria and moulds in milk and dairy products [19, 52-54].

Other studies, carried out to detect different microbial species (Enterobacter aerogenes, E. coli, Pseudomonas aeruginosa) inoculated in potable water, showed that $10^{2}-10^{4}$ cells $/ \mathrm{mL}$ is the lowest microbial concentration detectable by an e-nose [55].

As well as bacteria many fungal species were described to play an important role in the degradation of foodstuffs. Different species have been isolated from food and some studies have been performed on different fungal species isolated from cereal grain and from mouldy bread. The aims of these studies was to employ the e-noses for early detection and differentiation methods for fungal species prior to visible growth in cereal grains and bakery products [56-57]. The results indicate that sensor arrays could be used as rapid means for controlling and improving food product quality. Similar encouraging results were obtained in studies carried out on the detection of mycotoxigenic fungi in grains [58-59].

The studies described above analyzed gas mixtures from spoilage microorganisms previously isolated and inoculated in specific media (Table 2). A different approach is the direct detection of vapours in food samples. Subsequently, characterization of vapours by GC-MS was related to identification of contaminant microbes [60]. In these experiments, the e-nose is based on different gas sensors and the volatile compounds are estimated based on the individual sensor responses. All the results mentioned above are promising and further investigations to induce specific response patterns of the gas sensors may help both in the qualitative and quantitative analysis of food spoilage.

\section{Data analysis}

Data processing techniques, used to perform detection, classification and description functions associated with the e-noses often include PCA, CA, Discriminant Function Analysis (DFA), Neural Network and Fuzzy Logic. Improvement and integration of new techniques are currently developing in order to enhance the accuracy of the prediction models [30, 61-63]. The systems optimizing knowledge extraction from e-nose are highly sophisticated and need to perform mathematical/statistical methods to implement and improve data analysis.

This application area is a very complex area of research in different fields such as medicine and biology, therefore, it is beyond the scope of this review to analyze data processing systems and to draw conclusions concerning new analytic models. Excellent works, which the reader is referred to, have 
been published concerning this matter [16, 19, 64-67]. Table 3 lists e-noses and data processing methods referenced in this paper.

Table 2. Representative bacteria and fungi detected by e-nose and implicated in food spoilage.

\begin{tabular}{|c|c|c|}
\hline Food or drink & Bacterial and fungal species** & Literature cited \\
\hline Poultry & $\begin{array}{l}\text { Salmonella enteritidis§ } \\
\text { Escherichia coli§ } \\
\text { Listeria monocytogenes§ } \\
\text { Klebsiella pneumoniae } \ddagger \\
\text { Enterobacter cloacae } \ddagger \\
\text { Pseudomonas aeruginosa } \ddagger \\
\text { Acinetobacter calcoaceticus } \ddagger\end{array}$ & [50] \\
\hline Milk and dairy products & 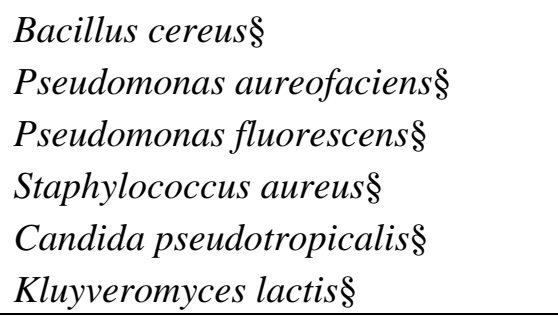 & {$[19,51-54]$} \\
\hline Water & $\begin{array}{l}\text { Enterobacter aerogenes§ } \\
\text { Escherichia coli§ } \\
\text { Pseudomonas aeruginosa§ }\end{array}$ & [55] \\
\hline Grains & $\begin{array}{l}\text { Fusarium moniliforme } \ddagger \\
\text { Fusarium proliferatum } \ddagger\end{array}$ & {$[56,58-59]$} \\
\hline Bakery products & $\begin{array}{l}\text { Eurotium amstelodami } \neq \\
\text { Eurotium chevalieri } \ddagger \\
\text { Penicillium chrysogenum } \ddagger\end{array}$ & {$[57]$} \\
\hline
\end{tabular}

** The microbial species were obtained from several culture collections (§) or isolated ( $\ddagger$ ) from food/drinks and were used in cultures to detect volatile organic compounds.

\section{Conclusions}

In this review we have described the applications of electronic odour sensing systems for microbial detection in the fields of health care and food technology. Published literature is considerable and explores different experimental conditions to develop and implement these new analysis methods.

In our opinion, there are two problems associated with the e-nose technology. The first problem concerns the instrument performance with regards to physical parameters (e. g. sensitivity, selectivity, reproducibility, stability) and data treatment. These aspects are being continually improved for rapid and better characterization of a large number of odours [61, 68-70].

The second problem is related to the experimental procedures performed to obtain specific responses for odour detection and identification. For this purpose, different approaches are proposed 
for sampling and providing specific information about the microorganism causative of disease or spoilage. The goals of these experiments are to identify the microbial species and/or to yield the chemical composition of the odours detected [71-75].

So far, the sensitivity of the human nose is far superior to that of any e-nose. Therefore, human panelists responses are still employed for odour classification. Solution to the listed problems and careful practical applications can provide rapid and useful tools in odours identification.

Table 3. Summary of commercially available e-noses, related sensors and data processing methods.

\begin{tabular}{|c|c|c|c|}
\hline E-nose & Number of Sensors & Data processing method & References \\
\hline $\begin{array}{l}\text { MOSES II, Lenmartz } \\
\text { Electronic, Tübingen, } \\
\text { Germany }\end{array}$ & $8 \mathrm{MOS}, 8 \mathrm{QMB}, 4$ AGS & PCA & {$[17]$} \\
\hline $\begin{array}{l}\text { BH-114, Bloodhound } \\
\text { Sensors Ltd, Leeds, UK }\end{array}$ & $14 \mathrm{CP}$ & PCA, DFA, CA, GA-NNs & $\begin{array}{c}{[18,22,31,35,41-42,} \\
51,55,57-58]\end{array}$ \\
\hline $\begin{array}{c}\text { Cyranose C320, Cyrano } \\
\text { Sciences, Pasadena, CA, } \\
\text { USA }\end{array}$ & $32 \mathrm{CP}$ & $\begin{array}{c}\text { PCA, PLS, FCM, SOM, PNN, } \\
\text { RBF }\end{array}$ & {$[26,30,33,38-40,61]$} \\
\hline $\begin{array}{l}\text { FOX, 2000, Alpha MOS, } \\
\text { Toulouse, France }\end{array}$ & $6 \mathrm{MOS}$ & PCA, NNs & [44-45] \\
\hline $\begin{array}{l}\text { Airsense Portable } \\
\text { E-Nose (PEN2), } \\
\text { Airsense Analytical, } \\
\text { Schwerin, Germany }\end{array}$ & $10 \mathrm{MOS}$ & PCA, ANNs, k-NN & [43] \\
\hline $\begin{array}{l}\text { FreshSense, Bodvaki- } \\
\text { Maritech, Kópavogur, } \\
\text { Iceland }\end{array}$ & $\begin{array}{c}4 \text { electrochemical for : } \\
\mathrm{CO}, \mathrm{H}_{2} \mathrm{~S}, \mathrm{SO}_{2}, \mathrm{NH}_{3}\end{array}$ & $\begin{array}{c}\text { Statistical analysis, Duncan's } \\
\text { multiple range }\end{array}$ & [60] \\
\hline $\begin{array}{c}\text { zNose }^{\mathrm{TM}} \text {, Electronic } \\
\text { Sensor Technology } \\
\text { Newbury Park, CA, USA }\end{array}$ & 1 SAW & $\begin{array}{c}\text { Reference to calibration } \\
\text { standards }\end{array}$ & {$[9-11,71]$} \\
\hline
\end{tabular}

Notes: MOS: Metal-Oxide Semiconductors; QMB: Quartz Microbalance; AGS: Amperometric Gas Sensors; CP: Conducting Polymers; SAW: Surface Acoustic Wave. PCA: Principal Components Analysis; DFA: Discriminant Function Analysis; CA: Cluster Analysis; GA-NNs: Genetic Algorithms, back propagation Neural Networks; PLS: Partial Least Squares; FCM: Fuzzy C Means; SOM: Self Organizing Map; PNN: Probabilistic Neural Network; RBF: Radial Basis Function; NNs: Neural Networks; ANNs: Artificial Neural Networks; k-NN: k-Nearest Neighbour algorithm. 


\section{Acknowledgments}

This work was supported by MIUR 60\% and Progetto FIRB n RBNE01P4B5-006.

\section{References}

1. Persaud, K.; Dodd, G. Analysis of discrimination mechanisms in the mammalian olfactory system using a model nose. Nature 1982, 299, 352-355.

2. Hines, E.L.; Llobet, E.; Gardner, J.W. Electronic noses: a review of signal processing techniques. IEE Proc. - Circuits, Devices Syst. 1999, 146, 297-310.

3. Gardner, J. W.; Hines, E. L.; Tang, H. C. Detection of vapours and odours from a multisensor array using pattern recognition. Part II. Artificial Neural Networks. Sens. Actuators B 1992, 9, 915.

4. Nordberg, A.; Hansson, M.; Sundh, I.; Nordkvist, E.; Carisson, H.; Mathisen, B. Monitoring of a biogas process using electronic gas sensors and near-infrared spectroscopy (NIR). Water Sci. Technol. 2000, 41, 1-8.

5. Hartmann, J.; Auge, J.; Hauptmann, P. Using the quartz-crystal-microbalance principle for gas detection with reversible and irreversible sensors. Sens. Actuators B 1994, 18, 429-433.

6. Ricco, J.; Crooks, R. M.; Osbourn, G. C. Surface acoustic wave chemical sensor arrays: new chemically sensitive interfaces combined with novel cluster analysis to detect volatile organic compounds and mixtures. Acc. Chem. Res. 1998, 31, 289-296.

7. Sisk, B. C; Lewis, N. S. Estimation of chemical and physical characteristics of analyte vapors through analysis of the response data of arrays of polymer-carbon black composite vapor detectors. Sens. Actuators B 2003, 96, 268-282.

8. Albert, K. J.; Walt, D. R.; Gill, D. S.; Pearce, T. C. Optical multibead arrays for simple and complex odor discrimination. Anal. Chem. 2001, 73, 2501-2508.

9. Staples, E. J; Watson, G. W. A gas chromatograph incorporating an innovative new surface acoustic wave (SAW) detector. Pittcon Conference, New Orleans, Louisiana, 1-5 March, 1998, Paper 1583CP.

10. Staples, E. J. A New Electronic Nose. Sensors 1999, 16, 33-40.

11. Staples, E. J. The $z \mathrm{Nose}^{\mathrm{TM}}$, a new electronic nose using acoustic technology. J. Acoust. Soc. Am. 2000, 108, 2495.

12. Bourgeois, W.; Romain, A. C.; Nicolas, J.; Stuetz, R. M. The use of sensor arrays for environmental monitoring: interests and limitations. J. Environ. Monit. 2003, 6, 852-860.

13. Tewari, J. C.; Irudayaraj, J. M. Floral classification of honey using mid-infrared spectroscopy and surface acoustic wave based z-Nose Sensor. J. Agric. Food Chem. 2005, 53, 6955-6966.

14. Zhu, L.; Seburg, R. A.; Tsai, E.; Puech, S.; Mifsud, J. C. Flavor analysis in a pharmaceutical oral solution formulation using an electronic-nose. J. Pharm. Biomed. Anal. 2004, 34, 453-461.

15. Ohmori, S.; Ohno, Y.; Makino, T.; Kashihara, T. Application of an electronic nose system for evaluation of unpleasant odor in coated tablets. Eur. J. Pharm. Biopharm. 2005, 59, 289-297.

16. Turner, A. P.; Magan, N. Electronic noses and disease diagnostics. Nat. Rev. Microbiol. 2004, 2, 161-166. 
17. McEntegart, C. M.; Penrose, W. R.; Strathmann, S.; Stetter, J. R. Detection and discrimination of coliform bacteria with gas sensor arrays. Sens. Actuators B 2000, 70, 170-176.

18. Magan, N.; Pavlou, A.; Chrysanthakis, I. Milk-sense: a volatile sensing system recognises spoilage bacteria and yeasts in milk. Sens. Actuators B 2001, 72, 28-34.

19. Ampuero, S.; Bosset, J. O. The electronic nose applied to dairy products: a review. Sens. Actuators B 2003, 94, 1-12.

20. Blixt, Y.; Borch, E. Using an electronic nose for determining the spoilage of vacuum packaged beef. Int. J. Food Microbiol. 1999, 46, 123-134.

21. Vinaixa, M.; Marin, S.; Brezmes, J.; Llobet, E.; Vilanova, X.; Correig, X.; Ramos, A.; Sanchis, $\mathrm{V}$. Early detection of fungal growth in bakery products by use of an electronic nose based on mass spectrometry. J. Agric. Food Chem. 2004, 52, 6068-6074.

22. Keshri, G.; Magan, N.; Voysey, P. Use of an electronic nose for the early detection and differentiation between spoilage fungi. Lett. Appl. Microbiol. 1998, 27, 261-264.

23. Parry, A. D.; Chadwick, P. R.; Simon, D.; Oppenheim, B.; McCollum, C. N. Leg ulcer odour detection identifies beta-haemolytic streptococcal infection. J. Wound Care. 1995, 4, 404-406.

24. Di Natale, C.; Macagnano, A.; Martinelli, E.; Paolesse, R.; D'Arcangelo, G.; Roscioni, C.; Finazzi-Agro, A.; D'Amico, A. Lung cancer identification by the analysis of breath by means of an array of non-selective gas sensors. Biosens. Bioelectron. 2003, 18, 1209.

25. Thaler, E. R.; Hanson, C. W. Medical applications of electronic nose technology. Expert Rev. Med. Devices 2005, 2, 559-566.

26. Machado, R. F.; Laskowski, D.; Deffenderfer, O.; Burch, T.; Zheng, S.; Mazzone, P. J.; Mekhail,T.; Jennings, C.; Stoller, J. K.; Pyle, J.; Duncan, J.; Dweik, R. A.; Erzurum, S. C. Detection of lung cancer by sensor array analyses of exhaled breath. Am. J. Respir. Crit. Care Med. 2005, 171, 1286-1291.

27. Aathithan, S.; Plant, J. C.; Chaudry, A. N.; French, G. L. Diagnosis of bacteriuria by detection of volatile organic compounds in urine using an automated headspace analyzer with multiple conducting polymer sensors. J. Clin. Microbiol. 2001, 39, 2590-2593.

28. Guernion, N.; Ratcliffe, N. M.; Spencer-Phillips, P. T.; Howe, R. A. Identifying bacteria in human urine: current practice and the potential for rapid, near-patient diagnosis by sensing volatile organic compounds. Clin. Chem. Lab. Med. 2001, 39, 893-906.

29. Kodogiannis, V.; Wadge, E. The use of gas-sensor arrays to diagnose urinary tract infections. Int. J. Neural Syst. 2005, 15, 363-376.

30. Yates, J. W.; Chappell, M. J.; Gardner, J. W.; Dow, C. S.; Dowson, C.; Hamood, A.; Bolt, F.; Beeby, L. Data reduction in headspace analysis of blood and urine samples for robust bacterial identification. Comput. Methods Programs Biomed. 2005, 79, 259-271.

31. Pavlou, A. K.; Magan, N.; McNulty, C.; Jones, J.; Sharp, D.; Brown, J.; Turner, A. P. Use of an electronic nose system for diagnoses of urinary tract infections. Biosens. Bioelectron. 2002, 17, 893-899.

32. Mohamed, E. I.; Bruno, E.; Linder, R.; Alessandrini, M.; Di Girolamo, A.; Poppl, S. J.; Puija, A.; De Lorenzo, A. A novel method for diagnosing chronic rhinosinusitis based on an electronic nose. An. Otorrinolaringol. Ibero Am. 2003, 30, 447-457. 
33. Hanson, C. W. 3rd, Thaler, E. R. Electronic nose prediction of a clinical pneumonia score: biosensors and microbes. Anesthesiology 2005, 102, 63-68.

34. Thaler, E. R.; Hanson, C. W. Use of an electronic nose to diagnose bacterial sinusitis. Am. J. Rhinol. 2006, 20, 170-172.

35. Pavlou, A. K.; Magan, N.; Jones, J. M.; Brown, J.; Klatser, P.; Turner, A. P. Detection of Mycobacterium tuberculosis (TB) in vitro and in situ using an electronic nose in combination with a neural network system. Biosens. Bioelectron. 2004, 20, 538-544.

36. Chandiok, S.; Crawley, B. A.; Oppenheim, B. A.; Chadwick, P. R.; Higgins, S.; Persaud, K. C. Screening for bacterial vaginosis: a novel application of artificial nose technology. J. Clin. Pathol. 1997, 50, 790-791.

37. Hay, P.; Tummon, A.; Ogunfile, M.; Adebiyi, A.; Adefowora, A. Evaluation of a novel diagnostic test for bacterial vaginosis: 'the electronic nose'. Int. J. STD AIDS 2003, 14, 114-118.

38. Lai, S. Y.; Deffenderfer, O. F.; Hanson, W.; Phillips, M. P.; Thaler, E. R. Identification of upper respiratory bacterial pathogens with the electronic nose. Laryngoscope 2002, 112, 975-979.

39. Shykhon, M. E.; Morgan, D. W.; Dutta, R.; Hines, E. L.; Gardner, J. W. Clinical evaluation of the electronic nose in the diagnosis of ear, nose and throat infection: a preliminary study. J. Laryngol. Otol. 2004, 118, 706-709.

40. Dutta, R.; Morgan, D.; Baker, N.; Gardner, J. W.; Hines, E. L. Identification of Staphylococcus aureus infections in hospital environment: electronic nose based approach. Sens. Actuators $B$ 2005, 109, 355-362.

41. Pavlou, A.; Turner, A. P. F.; Magan, N. Recognition of anaerobic bacterial isolates in vitro using electronic nose technology. Lett. Appl. Microbiol. 2002, 35, 366-369.

42. Pavlou, A. K.; Magan, N.; Sharp, D.; Brown, J.; Barr, H.; Turner, A. P. An intelligent rapid odour recognition model in discrimination of Helicobacter pylori and other gastroesophageal isolates in vitro. Biosens. Bioelectron. 2000, 15, 333-342.

43. Moens, M.; Smet, A.; Naudts, B.; Verhoeven, J.; Ieven, M.; Jorens, P.; Geise, H. J.; Blockhuys F. Fast identification of ten clinically important micro-organisms using an electronic nose. Lett. Appl. Microbiol. 2006, 42, 121-126.

44. Gardner, J. W.; Craven, M.; Dow, C.; Hines, E. L. The prediction of bacteria type and culture growth phase by an electronic nose with a multi-layer perceptron network. Meas. Sci. Technol. 1998, 9, 120-127.

45. Gardner, J. W.; Shin, H. W.; Hines, E. L. An electronic nose system to diagnose illness. Sens. Actuators B 2000, 70, 19-24.

46. Holmberg, M.; Gustafsson F.; Hörnsten, E. G.; Winquist, F.; Nilsson, L. E.; Ljung, L.; Lundström, I. Bacteria classification based on feature extraction from sensor data. Biotechnol. Tech. 1998, 12, 319-324.

47. Guth, H.; Grosh, W. Identification of the character impact odorants of stewed beef juice by instrumental analyses and sensory studies. J. Agric. Food Chem. 1994, 42, 2862-2866.

48. Hobbs, P. J.; Misselbrook, T. H.; Pain, B. F. Assessment of odors from livestock wastes by a photoionization detector, an electronic nose, olfactometry and gas-chromatography massspectrometry. J. Agric. Engin. Res. 1995, 60, 137-144. 
49. Rossi, V.; Talon, R.; Berdague, J. L. Rapid discrimination of Micrococcaceae species using semiconductor gas sensors. J. Microbiol. Meth. 1995, 24, 183-190.

50. Arnold, J. W.; Senter, S. D. Use of digital aroma technology and SPME GC-MS to compare volatile compounds produced by bacteria isolated from processed poultry. J. Sci. Food Agric. 1998, 78, 343-348.

51. Magan, N.; Pavlou, A.; Chrysanthakis, I. Milk-sense: a volatile sensing system recognises spoilage bacteria and yeasts in milk. Sens. Actuators B 2001, 72, 28-34.

52. Schaller, E.; Bosset, J. O.; Escher, F. Practical experience with 'electronic nose' systems for monitoring the quality of dairy products. Chimia 1999, 53, 98-102.

53. Marsili, R. T. SPME-MS-MVA as an electronic nose for the study of off-flavors in milk. J. Agric. Food Chem. 1999, 47, 648-654.

54. Marsili, R. T. Shelf-life prediction of processed milk by solid-phase microextraction, mass spectrometry, and multivariate analysis. J. Agric. Food Chem. 2000, 48, 3470-3475.

55. Canhoto, O. F.; Magan, N. Potential for the detection of microorganisms and heavy metals in potable water using electronic nose technology. Bios. Bioelectron. 2003, 18, 751-754.

56. Magan, N.; Evans, P. Volatiles as an indicator of fungal activity and differentiation between species, and the potential use of electronic nose technology for early detection of grain spoilage. J. Stored Prod. Res. 2000, 36, 319-340.

57. Keshri, G.; Voysey, P.; Magan, N. Early detection of spoilage moulds in bread using volatile production patterns and quantitative enzyme assays. J. Appl. Microbiol. 2002, 92, 165-172.

58. Keshri, G.; Magan N. Detection and differentiation between mycotoxigenic and nonmycotoxigenic strains of two Fusarium spp. using volatile production profiles and hydrolytic enzymes. J. Appl. Microbiol. 2000, 89, 825-33.

59. Olsson, J.; Borjesson, T.; Lundstedt, T.; Schnurer J. Detection and quantification of ochratoxin A and deoxynivalenol in barley grains by GC-MS and electronic nose. Int. J. Food Microbiol. 2002, 72, 203-214.

60. Olafsdottir, G.; Jonsdottir, R.; Lauzon, H.; Luten, J.; Kristbergsson, K. Characterization of volatile compounds in chilled cod (Gadus morhua) fillets by gas chromatography and detection of quality indicators by an electronic nose. J. Agric. Food Chem. 2005, 53, 10140-10147.

61. Dutta, R.; Hines, E. L.; Gardner, J. W.; Boilot, P. Bacteria classification using Cyranose 320 electronic nose. Biomed. Eng. Online 2002, 16, 1-4.

62. Carmel, L.; Levy, S.; Lancet, D.; Harel, D. A feature extraction method for chemical sensors in electronic noses. Sens. Actuators B 2003, 93, 67-76.

63. Tian, F.; Yang, S. X.; Dong, K. Circuit and Noise Analysis of Odorant Gas Sensors in an E-Nose. Sensors 2005, 5, 85-96.

64. Harper, W. J. The strengths and weaknesses of the electronic nose. Adv. Exp. Med. Biol. 2001, 488, 59-71.

65. Haugen, J. E. Electronic noses in food analysis. Adv. Exp. Med. Biol. 2001, 488, 43-57.

66. Hudon, G.; Guy, C.; Hewrmia, J. Measurement of odor intensity by an electronic nose. J. Air Waste Manag. Assoc. 2000, 50, 1750-1758. 
67. Logrieco, A.; Arrigan, D. W.; Brengel-Pesce, K.; Siciliano, P.; Tothill, I. DNA arrays, electronic noses and tongues, biosensors and receptors for rapid detection of toxigenic fungi and mycotoxins: a review. Food Addit. Contam. 2005, 22, 335-344.

68. Bos, A. Mass-producible and wireless wide-area networks of electronic noses: problems and solutions. Water Sci. Technol. 2004, 50, 153-160.

69. Gouma, P.; Sberveglieri, G. Novel materials and applications of electronic noses and tongues. MRS Bull. 2004, 29, 697-702.

70. Siripatrawan, U.; Linz, J. E.; Harte, B. R. Rapid method for prediction of Escherichia coli numbers using an electronic sensor array and an artificial neural network. J. Food Prot. 2004, 67, 1604-1609.

71. Casalinuovo, I. A.; Di Pierro, D.; Bruno, E.; Di Francesco, P.; Coletta, M. Experimental use of a new surface acoustic wave sensor for the rapid identification of bacteria and yeasts. Lett. Appl. Microbiol. 2006, 42, 24-29.

72. Nimmermark, S. Use of electronic noses for detection of odour from animal production facilities: a review. Water Sci. Technol. 2001, 44, 33-41.

73. Schnurer, J.; Olsson, J.; Borjesson, T. Fungal volatiles as indicators of food and feeds spoilage. Fungal Genet. Biol. 1999, 27, 209-217.

74. Younts, S.; Alocilja, E.; Osburn, W.; Marquie, S.; Gray, J.; Grooms, D. Experimental use of a gas sensor-based instrument for differentiation of Escherichia coli O157:H7 from non-O157:H7 Escherichia coli field isolates. J. Food Prot. 2003, 66, 1455-1458.

75. Jonsdottir, R.; Olafsdottir, G.; Martinsdottir, E.; Stefansson, G. Flavor characterization of ripened cod roe by gas chromatography, sensory analysis, and electronic nose. J. Agric. Food Chem. 2004, 52, 6250-6256.

(C) 2006 by MDPI (http://www.mdpi.org). Reproduction is permitted for noncommercial purposes. 